\title{
The role of storm flows in concentration of pesticides associated with particulate and dissolved fractions as a threat to aquatic ecosystems Case study: the agricultural watershed of Save river (Southwest of France)
}

\author{
L. Taghavi $i^{(1,2,3)}$, G. Merlina ${ }^{(1,2)}$, J.-L. Probst ${ }^{(1,2)}$ \\ Received July 28, 2010 / Reçu le 28 juillet 2010 \\ Revised December 15, 2010 / Révisé le 15 décembre 2010 \\ Accepted January 3, 2011 / Accepté le 3 janvier 2011
}

Key-words: pesticide, TSM, DOC, hysteresis patterns, flood flow

\section{ABSTRACT}

Measurement of the fluxes of pesticides was carried out for a year, ending in March 2009, in the Save catchment, in the vicinity of Toulouse. The hydrograph separation technique was used to evaluate the respective contribution of stormflow and baseflow in transport of 12 pesticide molecules. Transport of over $59 \%$ of pesticides and their controlling factors such as total suspended matter (TSM), particulate organic carbon (POC) and dissolved organic carbon (DOC) occurred during storm periods. Hysteresis patterns could be observed in the concentration-discharge relationships only for some molecules between rising and falling periods of the storm hydrograph. Clockwise hysteresis was noticed for low to moderately soluble pesticide molecules and for particulate fractions, which explains the role of surface runoff in pesticide displacement. In contrast, anticlockwise hysteresis was registered for soluble molecules and dissolved fractions, explaining the role of subsurface flows and soil leaching processes. The important role of TSM, POC and DOC in pesticide transport was clearly established. We also came to the conclusion that the role of stormy periods in pesticide movement and their controlling factors worked as a threat to aquatic ecosystems. And there was a positive relation between riverine TSM, POC, DOC and pesticides according to pesticide properties.

\section{RÉSUMÉ}

Le rôle des crues sur la concentration en pesticides associés aux fractions particulaires et dissoutes, une menace pour les écosystèmes aquatiques Cas d'étude : le bassin versant agricole de la rivière Save (sud-ouest de la France)

\author{
Mots-clés : \\ pesticide, \\ MES, COD, \\ hystérésis, \\ crue
}

\begin{abstract}
Les flux de pesticides sont mesurés durant une année hydrologique (2008-2009) sur le bassin versant de la Save, proche de Toulouse. La technique de séparation des hydrogrammes de crue a été utilisée pour évaluer la contribution respective des écoulements de crue et des écoulements de base au transport fluvial de 12 molécules de pesticides. Plus de $59 \%$ des flux de pesticides, de matières en suspension (MES), de carbone organique dissous (COD) et particulaire (COP) sont
\end{abstract}

(1) Université de Toulouse; INPT, UPS; Laboratoire Écologie Fonctionnelle et Environnement (EcoLab); ENSAT, avenue de l'Agrobiopole, 31326 Castanet Tolosan Cedex, France, jean-luc.probst@ensat.fr

(2) CNRS; EcoLab; ENSAT, 31326 Castanet Tolosan Cedex, France

(3) Department of Environment and Energy, Science and Research Branch, Islamic Azad University, Tehran, Iran 
transportés durant les périodes de crue. Des hystérésis peuvent être observées sur les relations concentrations-débits, uniquement pour quelques molécules, entre la montée et la descente de crue. Des hystérésis dextres (sens des aiguilles d'une montre) sont observées pour les molécules peu ou modérément solubles et pour les fractions particulaires montrant le rôle du ruissellement de surface dans le transfert des pesticides. Au contraire, des hystérésis senestres (sens inverse) sont observées pour les molécules solubles et les fractions dissoutes montrant le rôle des écoulements hypodermiques et du lessivage des sols. On a pu établir clairement le rôle important des MES, du COP et du COD dans le transport des pesticides. Les résultats obtenus nous montrent aussi le rôle joué par les épisodes de crue sur les transferts de pesticides et de leurs facteurs de contrôle, représentant un risque potentiel important de contamination des eaux et une menace pour les écosystèmes aquatiques. Des relations positives sont mises en évidence entre les teneurs en MES, COD ou COP et les concentrations en pesticides selon les propriétés physico-chimiques des différents pesticides.

\section{INTRODUCTION}

Increasing environmental awareness has generated concerns regarding the impact of pesticides on aquatic ecosystems. In a thorough investigation conducted by Palma et al. (2004) and Comoretto and Chiron (2005), a high degree of concentration was detected in surface water in a number of countries. Protecting aquatic organisms and people's health against hazardous situations resulting from the excessive use of pesticides has made it necessary for almost every country to reduce the presence of pesticides in surface water within concentration limits. For instance, the "Directive" concerning the quality of water intended for human consumption of the European Union foresees standards for pesticide residue in drinking water at $0.1 \mu \mathrm{g} \cdot \mathrm{L}^{-1}$ for each active substance and $0.5 \mu \mathrm{g} \cdot \mathrm{L}^{-1}$ for the sum of all pesticides (EEC, 1991). Higher rates of water contamination during storm events have been demonstrated by several investigators (Wu et al., 1983; Roth et al., 1992; Bach et al., 2001; Taghavi et al., 2010). However, little is known about the mechanisms of pesticide transfers from soils to stream waters, and about the parameters which control these transfers. It is therefore essential to examine and to verify the interaction of pesticides with their controlling factors such as total suspended matter (TSM), and particulate (POC) and dissolved (DOC) organic carbon in order to assess the impact of storm events on water quality and aquatic ecosystems.

The main objectives of this study are:

- to determine the pesticide concentrations and their temporal variations, particularly during storm flow events in an agricultural catchment: the Save river basin draining the Gascogne region in the Southwest of France;

- to assess the relationships between pesticide concentrations or their main controlling factors (TSM, DOC and POC contents) and the river discharge;

- to evaluate the role of the main controlling factors in pesticide transfers;

- to determine the contribution of the storm flow period to pesticide river fluxes using storm hydrograph separation.

\section{MATERIALS AND METHODS}

\section{$>$ WATERSHED DESCRIPTION}

The Save river, located in the "Coteaux de Gascogne" region (Southwest of France), drains an agricultural catchment with an area of $1110 \mathrm{~km}^{2}$ (Figure 1) at Larra station. The upstream part of the catchment is a hilly agricultural area mainly covered by forest and pasture $(56 \%)$, while the lower part is flat and devoted to intensive agricultural activities (44\%), mostly wheat, corn and sunflower, which make the use of pesticides indispensable. Non-calcic silty soils, locally named "boulbènes", represent less than $10 \%$ of the soils in this area. Calcic soils are 


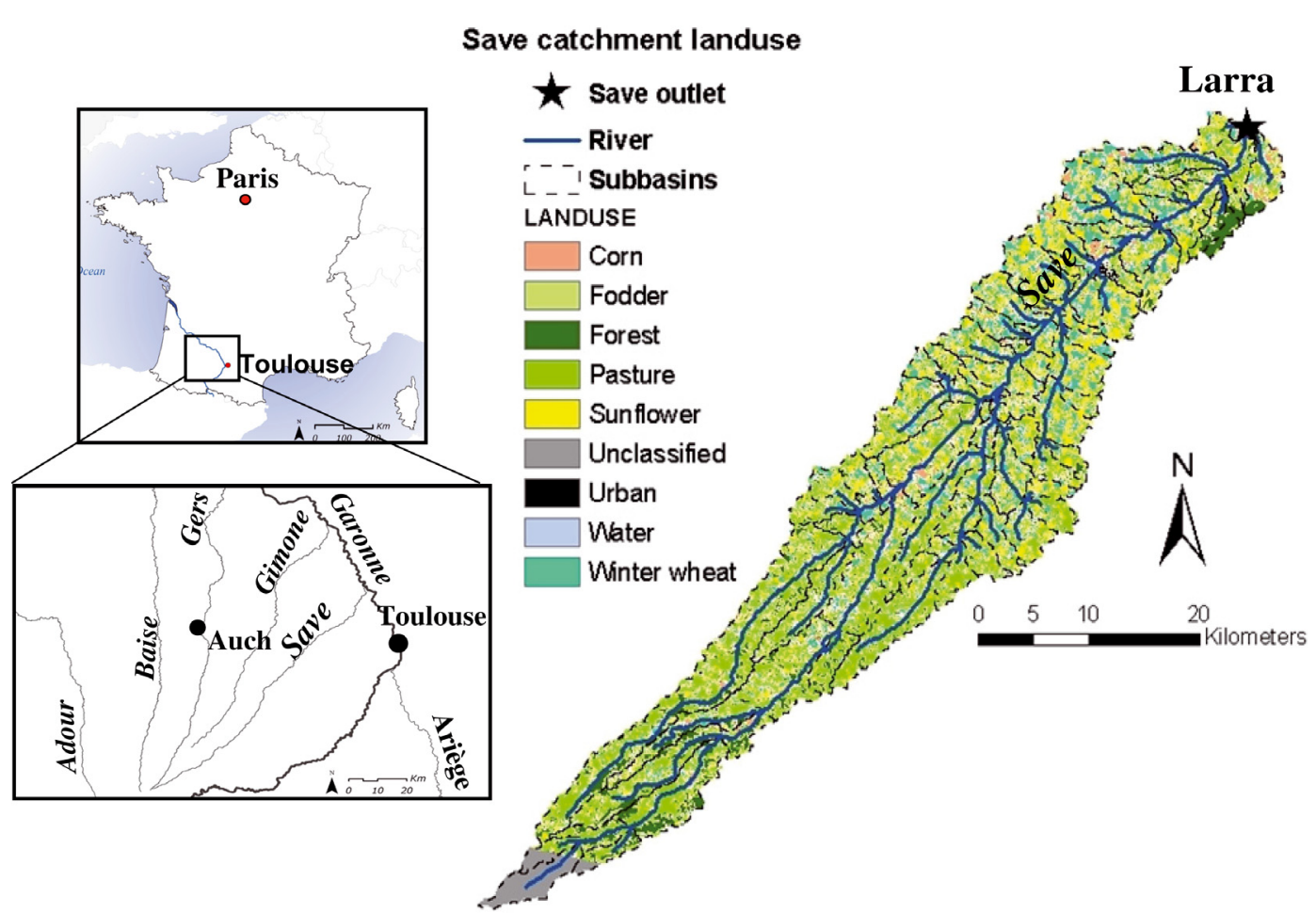

\section{Figure 1}

Location and land-use maps of the Save watershed with the position of Larra sampling station (star) at the outlet. The land-use map is extracted from Macary et al. (2006).

\section{Figure 1 \\ Cartes de localisation et d'utilisation des terres du bassin versant de la Save avec la position de la station d'échantillonnage, Larra, à l'exutoire du bassin (étoile). La carte d'utilisation des terres est extraite de Macary et al. (2006).}

dominated by clay content ranging from $40 \%$ to $50 \%$, while non-calcic soils are silty (50$60 \%)$. The geological substratum is a Miocene molassic deposit resulting from the erosion of the Pyrénées Mountains. This molassic substratum is impermeable due to its widely extended clay content that induces discharge into the river by surface and subsurface runoff. The climate is characterised as Atlantic-oceanic because the influence of the Atlantic ocean plays an important role in regulating temperature variations and therefore determining climate conditions. The average annual precipitation is about 700 to $900 \mathrm{~mm}$, mostly in the form of rain, which is the main hydrological source of supply for surface and subsurface runoff in this area, with the highest rate of discharge in February to June, while the water flows are lower from July to September.

\section{> SAMPLE COLLECTION}

Water sampling started in March 2008 and continued until March 2009. The main sampling months were February to June, with daily sampling during storm events. Outside the rainy period, water samples were collected manually each week.

Each sample was collected in the same big bottle and then it was split into three sub-samples. Two sub-samples were put into glass bottles of $2.5 \mathrm{~L}$ (for pesticide and TSM analyses) and one into a glass bottle of $500 \mathrm{~mL}$ (for DOC and POC analyses). The first one was used for pesticide analyses in unfiltered water; dichloramethane (DCM) was added in the field (1:40 V/V) to inhibit microbial degradation of the pesticides (Kreuger, 1998; Devault et al., 2007) and also used for extraction in the laboratory. The second one was filtered on $0.45-\mu \mathrm{m}$ cellulose ester Millipore 
filters for pesticide analyses in the filtrate after DCM extraction and for TSM measurements in the filters. The third one was filtered at $0.7 \mu \mathrm{m}$ on a Whatman GFF membrane for DOC (on the filtrate) and POC (on the filter) analyses. Concerning the results obtained and shown in this paper, we only concentrated on unfiltered water for pesticide concentrations.

The glass bottles used were carefully cleaned in the laboratory; then in the field they were rinsed three times to ensure representative samples. Sampling was done in an area where water is steady and continues flowing in immersion conditions. The glass bottles with Teflonlined lids were finally transported in ice-boxes and stored under refrigeration until analysed.

\section{>MEASUREMENTS OF TSM, DOC AND POC}

To measure total suspended matter (TSM), water samples were filtered by applying vacuum to a cellulose ester filter (Millipore, $0.45 \mu \mathrm{m}$ ) (Namiesnik et al., 1997). The sediment retained on the filter paper was dried for $24 \mathrm{~h}$ at $60{ }^{\circ} \mathrm{C}$ to ensure accurate sediment weight. The filter papers were then weighed before and after filtration to determine TSM concentration.

To analyse dissolved (DOC) and particulate (POC) organic carbon, the samples were filtered on a pre-combusted (by combusting it at $550{ }^{\circ} \mathrm{C}$ for $2 \mathrm{~h}$ ) Whatman GF/F with $0.7 \mu \mathrm{m}$ porosity. DOC measurement was carried out with an analyser of total organic carbon (Shimadzu TOC Analyser 5500). Before analysing DOC and in order to remove inorganic carbon, the samples were acidified by $\mathrm{HCL}(\mathrm{pH}<2)$. POC is measured by determining the mass lost upon combustion of a sample by using a CHN analyser (NA 2100).

\section{> PESTICIDE ANALYSES}

Twelve molecules of pesticides (herbicides and fungicides, see Table I) were investigated in this study based on the historical data of the French Water Agency Adour-Garonne and also on the studies performed by institutional networks (GRAMIP, for example). The selections of five families of pesticides were then further based on the study and on the availability of data of a 4-year-long study by Devault et al. (2007).

Pesticide analyses were performed by solvents of analytical grade (Pestipure by SDS, Solvent Documents Syntheses, Peypin, France). Anhydrous sodium sulphate from SDS was used for drying the organic phases. Pesticide Mix 44 prepared by Dr Ehrenstorfer (purchased from Cluzeau Information Laboratory (CIL), Sainte Foy-la-Grande, France) was used as reference material.

To extract water samples, the liquid/liquid extraction technique, the most common method, was applied (Tan, 1992), by using a shake flask (3-4 with a Teflon key) with dichloromethane as a solvent for phase exchange. The total water ratio was noted as $1: 6, \mathrm{~V} / \mathrm{V}$. Once the extraction was performed, dichloromethane was dried on $50 \mathrm{~g}$ anhydrous sodium sulphate, the remaining organic phase was evaporated under vacuum, and the dry residue was recuperated with $2 \mathrm{~mL}$ of hexane.

Pesticide molecules (herbicides, fungicides) have been analysed by the multi-residue technique in filtered and unfiltered waters (Devault et al., 2007; Taghavi et al., 2010). Gas chromatography coupled to mass spectrometry was used for separation and detection of different components. GC separation was done on a column of Zebra ZB-5MS $30 \mathrm{~m} 0.25-\mathrm{mm}$ i.d., 0.25-mm film from Phenomenex (Torrance CA) with a Thermo Fisher Scientific (Whatman, MA). A trace GC 2000 was coupled to a DSQ II mass detector. Extraction recoveries were done on spiked water samples with mixes of the different molecules analysed in this study by using Pesticide Mix 44 reference material and other different molecules separately (prepared by $\mathrm{Dr}$ Ehrenstorfer), although the complete analytical methodology is described in Taghavi et al. (2010). The limits of detection based on a signal to noise ratio of 3 vary from 0.001 to $0.003 \mu \mathrm{g} \cdot \mathrm{L}^{-1}$ according to the molecules. 


\section{Table I}

Statistical summary of detection frequencies and concentration levels of the different pesticides measured in the water samples collected at the outlet of the Save watershed from March 2008 to March 2009.

\section{Tableau I}

Récapitulatif statistique des fréquences de détection et des niveaux de concentration observés pour les différents pesticides mesurés dans les échantillons d'eau prélevés à l'exutoire du bassin versant de la Save de mars 2008 à mars 2009.

\begin{tabular}{|c|c|c|c|c|c|c|c|}
\hline Molecules & Type & $\begin{array}{c}\text { Number of detections } \\
\text { during whole } \\
\text { period }(n=65)\end{array}$ & $\begin{array}{c}\% \text { DF during } \\
\text { whole } \\
\text { period }\end{array}$ & $\begin{array}{l}\text { Number of detections } \\
\text { during stormy } \\
\text { periods }(n=41)\end{array}$ & $\begin{array}{l}\text { \% DF during } \\
\text { storm } \\
\text { events }\end{array}$ & $\begin{array}{l}\text { Average } \\
\left.\text { C (ug. } L^{-1}\right)\end{array}$ & $\begin{array}{l}\text { Maximum } \\
C\left(\mu g \cdot L^{-1}\right)\end{array}$ \\
\hline Chlortoluron & Herbicide & 64 & 98 & 40 & 98 & 0.391 & 1.97 \\
\hline Isoproturon & Herbicide & 62 & 95 & 40 & 98 & 0.144 & 1.16 \\
\hline Linuron & Herbicide & 58 & 89 & 37 & 90 & 0.270 & 1.65 \\
\hline Metolachlor & Herbicide & 64 & 98 & 40 & 98 & 0.197 & 0.95 \\
\hline Alachlor & Herbicide & 46 & 71 & 28 & 68 & 0.007 & 0.05 \\
\hline Aclonifen & Herbicide & 60 & 92 & 39 & 95 & 0.144 & 1.34 \\
\hline Trifluralin & Herbicide & 54 & 83 & 34 & 83 & 0.076 & 0.51 \\
\hline Fenpropimorph & Fungicide & 53 & 82 & 36 & 88 & 0.004 & 0.02 \\
\hline Fluzilazol & Fungicide & 65 & 100 & 41 & 100 & 0.010 & 0.07 \\
\hline Cyproconazol & Fungicide & 50 & 77 & 29 & 71 & 0.020 & 0.12 \\
\hline Tebuconazol & Fungicide & 63 & 97 & 40 & 98 & 0.255 & 0.778 \\
\hline Epoxiconazol & Fungicide & 65 & 100 & 41 & 100 & 0.165 & 0.11 \\
\hline
\end{tabular}

DF: Detection frequency.

C: Concentration.

\section{> FLUX CALCULATION}

The flux is defined as the mass of the compound transported in the river at each sampling point during a specified time period. The fluxes of pesticide, TSM and DOC are calculated for each sampling interval $(i$ to $i+1)$ as the product of discharge weighted concentration $C$ $\left(C_{i}\right.$ to $\left.i+1=\left(C_{i} Q_{i}+C_{i+1} Q_{i+1}\right) /\left(Q_{i}+Q_{i+1}\right)\right)$ and river discharge $(Q)$ during the time interval i to $i+1$. The storm event fluxes and the annual fluxes are calculated by summing the fluxes of the different intervals ( $i$ to $n$ ). Hourly mean discharge values were available for all sampling points for the entire investigation periods from CACG (Compagnie d'Aménagement des Coteaux de Gascogne), in charge of the Larra gauging station. This method is common in the literature to estimate the flux of the organic carbon, the total suspended matter and the pesticide (Walling and Webb, 1985; Hope et al., 1997; Worrall and Burt, 2004; Clark et al., 2007).

\section{> STATISTICAL ANALYSIS}

SPSS 11 software (SPSS Inc., Chicago, IL, USA) was used to carry out the statistical analysis of the data set. The significance of correlations was tested by using Pearson or Spearman tests.

\section{RESULTS}

\section{> WATERSHED HYDROLOGY}

All of the runoff events were monitored and analysed for a year, ending in March 2009. The discharges measured for each storm event were plotted hourly on an $x$-axis as an hourly discharge hydrograph. The discharge measured in a stream is a combination of these three main flow components: surface runoff, subsurface runoff and groundwater flow (Figure 2). 

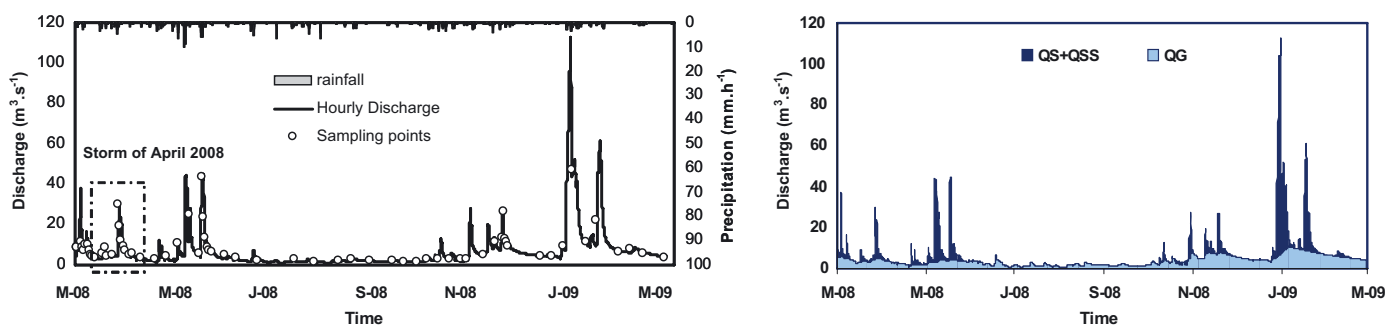

\section{Figure 2}

Variations in the Save river discharge during the study period (March 2008-March 2009), position of the samplings (white circles) (left) and separation of the total river discharge into storm flows (surface runoff QS plus subsurface flow QSS) and baseflow QG (right).

\section{Figure 2}

Variations des débits de la Save au cours de la période d'étude (mars 2008-mars 2009) et position des points d'échantillonnage (cercles blancs) (à gauche) et séparation du débit fluvial en ces deux composantes : écoulement de crue (ruissellement de surface QS plus écoulement hypodermique QSS) et écoulement de nappe QG (à droite).

The hydrograph separation method proposed by Probst (1985) and based on Maillet's equation $\left(Q_{t}=Q_{0} \mathrm{e}^{-\alpha t}\right)$ with some modification was applied for separating the stormy periods. To check the relationship between pesticide concentrations and their controlling factors with discharge of water we paid particular attention to the storm of April 2008 since this period coincides with the pesticide application period and, moreover, our sampling points covered nearly all of the storm phases (rising and falling).

\section{> CONCENTRATION OF PESTICIDES IN RIVER WATER}

Pesticides were detected in almost every stream water sample collected at the outlet of the Save watershed. The overall frequency levels at which pesticides were identified during the year-long observation are statistically summarised in Table I.

The highest rate of concentration $1.97\left(\mu \mathrm{g} \cdot \mathrm{L}^{-1}\right)$ was recorded for chlortoluron and the lowest rate was detected at $0.02 \mu \mathrm{g} \cdot \mathrm{L}^{-1}$ for fenpropimorph.

The highest and lowest mean concentrations were calculated at 0.391 and $0.004 \mu \mathrm{g} \cdot \mathrm{L}^{-1}$, respectively, for chlortoluron and fenpropimorph.

\section{> PESTICIDE, TSM AND DOC RIVERINE FLUXES}

During the entire investigation period, 41 out of 65 water samples were taken during storm periods in order to determine the total pesticides, TSM and DOC fluxes. The hydrograph separation method was used to distinguish the contribution of the storm period (mainly supplied by surface and subsurface runoff) from that of baseflow (mainly supplied by groundwater flows). Our findings revealed over $59 \%$ of the studied molecules were transported during the storm periods and the percentages of pesticides in baseflow remained several times less than those in storm flow despite the relatively significant water contribution of baseflow (36.1\%) to the annual river discharge. In the present study, $63.9 \%$ of the water volume discharged annually by the Save river, nearly $71 \%$ of DOC river fluxes and $94 \%$ of TSM exported by the river were transported during the flood events. Concerning pesticide river fluxes (Table II), $59 \%$ to $90 \%$ are exported during the storm flow periods according to the molecules.

\section{> CONCENTRATION-DISCHARGE RELATIONSHIPS: HYSTERESIS PATTERNS}

Hysteresis is a circular pattern relationship between dissolved or particulate concentration and river discharge which can be observed during a storm event. The results presented 


\section{Table II}

Respective contribution (in \%) of storm flow and baseflow periods to the total riverine fluxes of water, TSM, DOC and pesticide during the period March 2008-March 2009.

Tableau II

Contribution respective (en \%) des périodes de crues et des écoulements de base aux flux totaux d'eau, de MES, de COD et de pesticides exportés par la rivière au cours de la période mars 2008-mars 2009.

\begin{tabular}{|l|c|c|c|c|c|c|c|c|c|c|c|c|c|c|c|c|}
\hline Period & $\begin{array}{c}\text { Duration } \\
\text { (day) }\end{array}$ & $\begin{array}{c}\text { Chl } \\
\%\end{array}$ & $\begin{array}{c}\text { Iso } \\
\%\end{array}$ & $\begin{array}{c}\text { Lin } \\
\%\end{array}$ & $\begin{array}{c}\text { Met } \\
\%\end{array}$ & $\begin{array}{c}\text { Ala } \\
\%\end{array}$ & $\begin{array}{c}\text { Acl } \\
\%\end{array}$ & $\begin{array}{c}\text { Tri } \\
\%\end{array}$ & $\begin{array}{c}\text { Fen } \\
\%\end{array}$ & $\begin{array}{c}\text { Flu } \\
\%\end{array}$ & $\begin{array}{c}\text { Cyp } \\
\%\end{array}$ & $\begin{array}{c}\text { Teb } \\
\%\end{array}$ & $\begin{array}{c}\text { Epo } \\
\%\end{array}$ & $\begin{array}{c}\text { TSM } \\
\%\end{array}$ & $\begin{array}{c}\text { DOC } \\
\%\end{array}$ & $\begin{array}{c}\text { Volume } \\
\text { water } \%\end{array}$ \\
\hline Storm flow & 142 & 73.4 & 59.2 & 86.2 & 88.6 & 76.6 & 90.1 & 74 & 72.8 & 67.6 & 86 & 80.2 & 77 & 94.2 & 71 & 63.9 \\
\hline Baseflow & 223 & 26.6 & 40.8 & 13.8 & 11.4 & 23.4 & 9.9 & 26 & 27.2 & 32.4 & 14 & 19.8 & 23 & 5.8 & 29 & 36.1 \\
\hline
\end{tabular}

Here are the abbreviated symbols of the 12 molecules under observation: trifluralin (Tri), aclonifen (Acl), fenpropimorph (Fen), tebuconazol (Teb), fluzilazol (Flu), epoxiconazol (Epo), alachlor (Ala), linuron (Lin), cyproconazol (Cyp), metolachlor (Met), isoproturon (iso), chlortoluron (chl).

in this part concern three selected molecules of pesticides with varying degrees of solubility. Solubility $\left(S_{\mathrm{w}}\right.$ in $\left.\mathrm{mg} \cdot \mathrm{L}^{-1}\right)$ and different $K_{\text {ow }}$ (octanol-water partitioning coefficient) values are used as indicators for estimating bioaccumulation in animals and plants and in predicting the toxic effects of substances (Veith et al., 1979; Briggs, 1981; Calamari and Vighi, 1990). The latter values for the three molecules under investigation are: aclonifen, a low-solubility molecule $\left(K_{\mathrm{ow}}=4.37, S_{\mathrm{w}}=1.4\right)$, linuron as a moderately soluble molecule $\left(K_{\mathrm{ow}}=3\right.$ and $\left.S_{\mathrm{w}}=63.5\right)$ and metolachlor, representative of a highly soluble molecule $\left(K_{\mathrm{ow}}=2.9, S_{\mathrm{w}}=488\right)$. $C-Q$ relationships present generally hysteresis patterns, showing that the concentration is different between the rising and the falling period of the hydrograph for the same river discharge. Two cases can be observed according to the transfer dynamic of the molecule from the soils to the river waters:

- Clockwise hysteresis is produced when concentration is higher during the rising limb than during the falling limb of the hydrograph. This is the case for aclonifen and linuron molecules.

- Anticlockwise hysteresis appears when a higher concentration is noticeable during the falling limb of the hydrograph, i.e. during the recession period, as is the case for metolachlor.

These results indicate that transport of metolachlor (a soluble molecule) is primarily controlled by subsurface water flow, whose contribution is at the highest during the falling limb of the flood hydrograph. DOC also shows anticlockwise hysteresis, which explains the highest concentration of DOC occurring in the falling stage of the storm period, which coincides with the time of draining of different hydrological reservoirs, particularly soil leaching. On the contrary, clockwise hysteresis shows that the surface runoff, whose contribution is maximum during the rising limb of the flood, is controlling the transfer of aclonifen (a low-solubility molecule) and linuron (a moderately soluble molecule) that are strongly associated with TSM and POC, which present the same hysteresis patterns as these molecules. The different patterns of hysteresis observed in our study are depicted in Figure 3.

\section{> TSM, POC AND DOC AS VECTORS OF PESTICIDE TRANSPORT}

Properties of pesticides play a major role in influencing their concentration in runoff. Pesticide can be adsorbed onto eroded particles and transported into the river water by the total suspended matter (TSM). They can also be complexed by dissolved organic carbon (DOC), which is regarded as the main sorbent for hydrophilic pesticides in soil/water. Our results revealed that molecules with low to moderate solubility such as aclonifen and linuron are exported in association with TSM and POC, since there is a significant interaction between the concentration of aclonifen and the concentrations of TSM and POC (Figure 4). Metolachlor, as a molecule with a high degree of solubility, shows a good relationship with DOC, which highlights the important role of DOC as a vector in transporting hydrophilic pesticides such as metolachlor (Figure 4). 

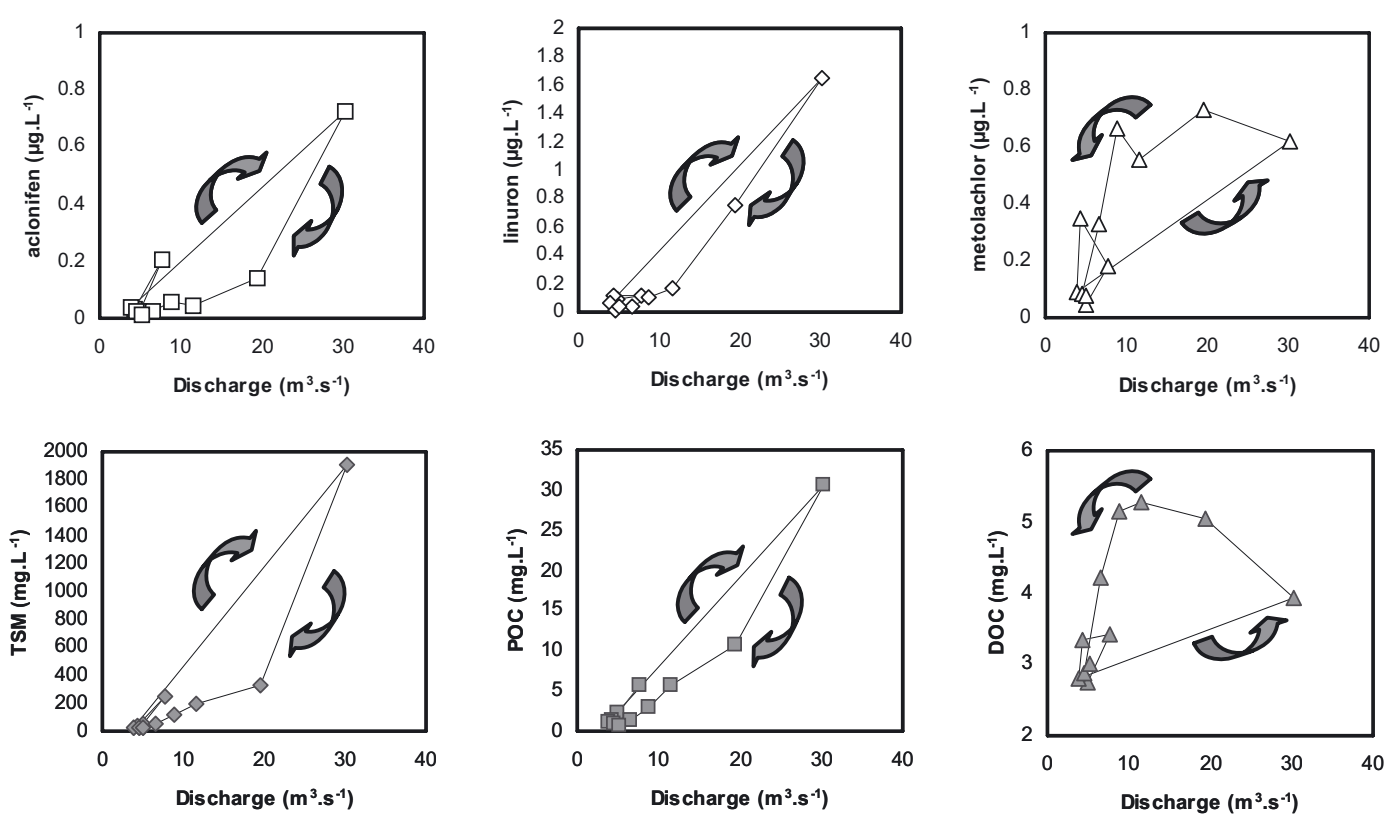

Figure 3

Relationships between the concentrations of TSM, DOC, POC, aclonifen, linuron and metolachlor and the Save river discharge during the storm event of April 2008 at Larra station. The direction of the hysteresis pattern is given by the arrows: clockwise for TSM, POC aclonifen and linuron, anticlockwise for DOC and metolachlor.

\section{Figure 3}

Relations entre les concentrations en MES, COD, COP, aclonifène, linuron ou métolachlore et les débits de la Save au cours de la crue d'avril 2008. Le sens des hystérésis est indiqué par les flèches : dextres pour MES, COP, aclonifène et linuron, senestres pour COD et métolachlore.
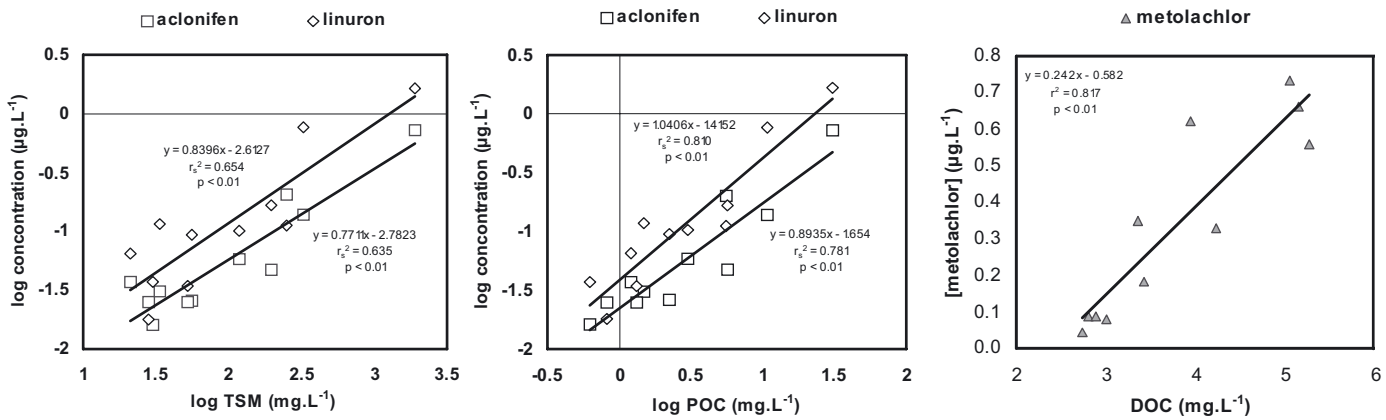

Figure 4

Relationships between the concentrations of some selected pesticide molecules (aclonifen, linuron and metolachlor) and their controlling factors (TSM, POC and DOC) during the storm event of April 2008 for the Save river at Larra station.

Figure 4

Relations entre les concentrations en pesticides (aclonifène, linuron et métolachlore) et leurs facteurs de contrôle (MES, COP et COD) au cours de la crue d'avril 2008 sur la Save à la station de Larra. 


\section{DISCUSSION}

This careful survey of pesticide concentrations, particularly during storm flow events, showed that pesticides are mainly exported during these hydrological periods. These periods are very short temporal events but very intense in the Gascogne region (Southwest of France), which is intensively cultivated (mainly corn, wheat and sunflower). Our findings revealed that more than $59 \%$ of pesticides are transported during storm events into river systems. Results obtained by previous studies indicate that pesticide transport and losses are related to some phenomena which generally appear close to the application periods (Brown et al., 1995; Lennartz et al., 1997). Moreover, the characteristics of rainfall, runoff volume and storm events have a great impact on pesticide transport and losses (Muller et al., 2003). The role of stormy periods is highlighted in transport of TSM and DOC, and the findings are in accordance with the survey results of Clark et al. (2007), Zhang et al. (2009) and Ollivier et al. (2010). A cyclical trajectory relationship (hysteresis) has already been reported between river discharge and solute concentration during storm events (Jardine et al., 1990; Hill, 1993). However, none of these studies have shown the hysteresis phenomenon for pesticide molecules, and pesticide transport has rarely been observed from this particular angle. The hysteresis patterns allow us to assess the potential contribution of different stream flow components in pesticide exportation and their controlling factor displacement. Clockwise hysteresis shows the important role of surface runoff and mechanical erosion in transport of particulate elements such as aclonifen as a low-solubility molecule and linuron, a molecule with moderate solubility, both of which were transferred from the soils to the river waters by surface runoff. Moreover, TSM and POC also show a similar pathway of transport. Previous studies have shown the important role of surface water in transport of low-solubility elements such as phosphorus and total suspended matter (Probst, 1985; Probst and Bazerbachi, 1986). Anticlockwise hysteresis highlighted the role of subsurface water in transport of metolachlor and DOC. The findings of Probst (1985), Kattan et al. (1986) and Wagner et al. (2008) have revealed the role of subsurface water in transport of other soluble elements, such as nitrate. This result confirms the pre-eminent role of subsurface flow in metolachlor and DOC displacement, and both of them are transported with each other by complexation processes. TSM and POC play an important role in transport of aclonifen and linuron by adsorption processes onto organic or inorganic particulate fractions. This conclusion is strongly supported by the very good relationship between metolachor and DOC, and also between aclonifen or linuron and TSM or POC. The study conducted by Taghavi et al. (2010) in a small agricultural catchment, Montoussé in Auradé (320 ha), also highlights the role of TSM in aclonifen transport, whereas linuron shows a good relationship with DOC. We could therefore conclude that for moderately soluble molecules such as linuron the partitioning between dissolved and particulate phases depends on the relative concentration of dissolved and particulate fractions, which both play an important role in linuron transport. Overall, our results revealed that a high concentration of pesticides is a serious external threat to water contamination and aquatic organism health, especially during storm periods when we have a large quantity of TSM, POC and DOC.

In 1984, Schubel and Carter pointed out pesticide associated with suspended particles may have different environmental effects in aquatic ecosystems than dissolved pesticide since suspended particles are a primary source of nutrition for filter-feeding organisms such as clams. However, both dissolved and particulate fractions are considered as potentially harmful elements to aquatic organisms. This is in agreement with the findings of Frankart et al. (2002).

A closer look at the data in this paper indicates that:

- $59 \%$ to $90 \%$ of pesticide, $94 \%$ of TSM and $70 \%$ of DOC are transported during flood periods, representing a potential vector for the transport of pesticides adsorbed onto these fractions and a potential contamination risk for aquatic ecosystems;

- the concentration-discharge relationships exhibit a hysteresis phenomenon with different concentrations during the falling and the rising limbs of the hydrograph, showing that the potential contamination risk for ecosystems is different according to the hydrological 
phases of the storm flow period and according to the physico-chemical characteristics of the molecules.

Higher contamination risks for aquatic ecosystems can be observed:

- for low-solubility molecules such as aclonifen during the rising water period due to the maximum contribution of mechanical erosion and surface runoff;

- for soluble molecules such as metolachlor during the recession period (falling water period) due to the maximum contribution of soil leaching and subsurface flows.

This study is centred on putting forward the essential parameters for an accurate theoretical model of pesticide transport into aquatic ecosystems. Understanding the role and influence of TSM, POC and DOC parameters is therefore needed in introducing such a model.

\section{ACKNOWLEDGEMENTS}

This study was supported by CPER (Midi-Pyrénées region) and FEDER (European Commission) funds within the framework of the IMAQUE (IMpact des Activités agricoles sur Qualite des Eaux, des sols, des sédiments et des milieux aquatiques) project and INSOLEVIE interregional project (Aquitaine and Midi-Pyrénées). Lobat Taghavi benefits from a Ph.D. fellowship from the Karoon Khozistan Company (Iran).

\section{REFERENCES}

Bach M., Huber A. and Frede H.G., 2001. Input pathways and river load of pesticides in Germany a national scale modelling assessment. Water Sci. Technol., 43, 261-268.

Briggs G.G., 1981. Theoretical and experimental relationship between soil adsorption octanol-water partition coefficient water solubility, bioconcentration factors, and the parachor. J. Agric. Food. Chem., 29, 1050-1059.

Brown C.D., Hodgkinson R.A., Rose D.A., Syers J.K. and Wilcockson S.J., 1995. Movement of pesticides to surface waters from a heavy clay soil. Pestic. Sci., 43, 131-140.

Calamari D. and Vighi M., 1990. Quantitative structure activity relationships in ecotoxicology: Value and limitations. Reviews Environ. Toxicol., 4, 1-112.

Clark J.M., Lane S.N., Chapman P.J. and Adamson J.K., 2007. Export of dissolved organic carbon from an upland peatland during storm events: Implications for flux estimates. J. Hydrol., 347, 438-447.

Comoretto L. and Chiron S., 2005. Comparing pharmaceutical and pesticide loads into a small Mediterranean river. Sci. Total Environ., 349, 201-210.

Devault D., Merlina G., Lim P., Probst J.-L. and Pinelli E., 2007. Multi-residues analysis of pre-emergence herbicides in fluvial sediments: application to the mid-Garonne River. J. Environ. Monit., 9, 10091017.

European Economic Community (EEC), 1991. European Union Council directive 91/414/EEC, 1991.

Frankart C., Eullaffroy P. and Vernet G., 2002. Photosynthetic responses of Lemna minor exposed to xenobiotics, copper, and their combinations. Ecotoxicol. Environ. Safety, 53, 439-445.

Hill A.R., 1993. Nitrogen dynamics of storm runoff in the riparian zone of forested watershed. Biogeochemistry, 20, 19-44.

Hope D., Billet M.F. and Cresser M.S., 1997. Exports of organic carbon in two river systems in NE Scotland. J. Hydrol., 193, 61-82.

Jardine P.M., Wilson G.V., McCarthy J.F., Luxmoore R.J. and Taylor D.L., 1990. Hydrogeochemical processes controlling the transfer of dissolved organic carbon through a forested hillslope. J. Contaminant Hydrol., 6, 3-19.

Kattan Z., Salleron J.L. and Probst J.-L., 1986. Bilans et dynamiques de transfert de l'azote et du phosphore sur le bassin de la Moselle (Nord-Est de la France). Sciences de l'Eau, 5, 435-459.

Kreuger J., 1998. Pesticides in stream water within an agricultural catchment in southern Sweden 19901996. Sci. Total Environ., 216, 227-251. 
Lennartz B., Louchart X., Voltz M. and Andrieux P., 1997. Diuron and Simazine losses to runoff water in Mediterranean vineyards. J. Environ. Qual., 26, 1493-1502.

Macary F., Lavie E., Lucas G. and Riglos O., 2006. Méthode de changement d'échelle pour l'estimation du potentiel de contamination des eaux de surface par l'azote. Ingénieries-EAT, 46, 35-49.

Muller K., Deurer M., Hartmann H., Bach M., Spiteller M. and Frede H.G., 2003. Hydrological characterisation of pesticide loads using hydrograph separation at different scales in a German catchment. J. Hydrol., 273, 1-17.

Namiesnik J., Jamrogiewicz Z., Pilarczyk M. and Torres L., 1997. Preparation of environmental samples for analysis. Chem. Inz. Ekol., 4, 3-128.

Ollivier P., Hamelin B. and Radakovitch O., 2010. Seasonal variations of physical and chemical erosion: A three-year survey of the Rhone River (France). Geochim. Cosmochim. Acta, 74, 907-927.

Palma G., Sanchez A., Olave Y., Encina F., Palma R. and Barra R., 2004. Pesticide levels in surface waters in an agricultural forestry basin in Southern Chile. Chemosphere, 57, 763-770.

Probst J.-L., 1985. Nitrogen and phosphorus exportation in the Garonne basin (France). J. Hydrol., 76, 281-305.

Probst J.-L. and Bazerbachi A., 1986. Transports en solution et en suspension par la Garonne supérieure. Sci. Géol. Bull., 39, 79-98.

Roth C.H. and Helming K., 1992. Dynamics of surface sealing runoff and interrill soil loss as related to rainfall intensity microrelief and slope. Z. Pflanzenemahr. Bodenk., 155, 209-216.

Schubel J.R. and Carter H.H., 1984. The estuary as a filter for fine grained suspended sediment. In: Kennedy V.S. (ed.), The estuary as a filter, New York, N.Y., Academic, 81-105.

Taghavi L., Probst J.-L., Merlina G., Marchand A.L., Durbe G. and Probst A., 2010. Flood event impact on pesticide transfer in a small agricultural catchment (Montoussé at Auradé, south west France). Intern. J. Environ. Anal. Chem., 90, 390-405.

Tan G.H., 1992. Comparison of solvent extraction and solid phase extraction for determination of organochlorine pesticide residues in water. Analyst, 117, 1129-1132.

Veith G.D., Defoe D.L. and Bergstedt B.V., 1979. Measuring and estimating the bioconcentration factor of chemicals in fish. J. Fish Res. Board Can., 36, 1040-1046.

Wagner L.E., Vidon P., Tedesco L.P. and Gray M., 2008. Stream nitrate and DOC dynamics during spring storms across land uses in glaciated landscapes of the Midwest. J. Hydrol., 362, 177-190.

Walling D.E. and Webb B.W., 1985. Estimating the discharge of contaminants to coastal waters by rivers: Some cautionary comments. Marine Pollution Bulletin, 16, 488-492.

Worrall F. and Burt T., 2004. Time series analysis of long-term river dissolved organic carbon trends. Hydrological Processes, 18, 893-911.

Wu T.L., Correll D.L. and Remenapp H.E.H., 1983. Herbicide runoff from experimental watersheds. J. Environ. Qual., 12, 330-336.

Zhang S., Lu X.X., Sun H., Han J. and Higgitt D.L., 2009. Geochemical characteristics and fluxes of organic carbon in a human-disturbed mountainous river (the Luodingjiang River) of the Zhujiang (Pearl River) China. Sci. Total Environ., 407, 815-825. 